\title{
Sanitary Risks Connected to the Consumption of Infusion from Senna rotundifolia L. Contaminated with Lead and Cadmium in Cotonou (Benin)
}

\author{
S. A. Montcho, ${ }^{1}$ K. Koudouvo, ${ }^{2}$ A. P. E. Yehouenou, ${ }^{3}$ P. Guedenon, ${ }^{1}$ \\ L. Koumolou, ${ }^{1}$ M. Oke Sopoh, ${ }^{4}$ V. Dougnon, ${ }^{1}$ Mensavi F. Gbéassor, ${ }^{2}$ E. E. Creppy, ${ }^{5}$ \\ M. Boko, ${ }^{6}$ and A. P. Edorh ${ }^{1,7}$ \\ ${ }^{1}$ Interfaculty Centre of Training and Research in Environment for Sustainable Development (CIFRED), \\ University of Abomey-Calavi (UAC), Jéricho, 03 BP 1463 Cotonou, Benin \\ ${ }^{2}$ Department of Physiology/Pharmacology, Faculty of Science, University of Lomé (UL), BP 1515, Lomé, Togo \\ ${ }^{3}$ Laboratory of Applied Research in Biology (LARBA), Genie Environment Department of Polytechnic University (EPAC), \\ University of Abomey-Calavi (UAC), 01 BP 526 Cotonou, Benin \\ ${ }^{4}$ National Programme for Malaria Control (PNLP), Ministry of Health, Akpakpa, 01 BP 882 Cotonou, Benin \\ ${ }^{5}$ Laboratory of Toxicology and Applied Hygiene/UFR of Pharmaceutical Sciences, 146 Street Léo Saignat, \\ 33076 Bordeaux Cedex, France \\ ${ }^{6}$ Laboratory Pierre Pagney: Climate, Water, Ecosystem and Development (LACEEDE), Faculty of Arts and Human Sciences, \\ University of Abomey-Calavi, 03 BP 1122 Cotonou, Benin \\ ${ }^{7}$ Department of Biochemistry and Cellular Biology, University of Abomey-Calavi (UAC), 01 BP 526 Cotonou, Benin
}

Correspondence should be addressed to S. A. Montcho; smontcho19@yahoo.fr

Received 13 July 2013; Revised 27 October 2013; Accepted 11 November 2013; Published 29 January 2014

Academic Editor: Orish Ebere Orisakwe

Copyright (c) 2014 S. A. Montcho et al. This is an open access article distributed under the Creative Commons Attribution License, which permits unrestricted use, distribution, and reproduction in any medium, provided the original work is properly cited.

\begin{abstract}
This study carried out an assessment of sanitary risks connected to the consumption of Senna rotundifolia Linn. contaminated with lead and cadmium. This plant was collected and analyzed by atomic absorption spectrophotometry. The results revealed a contamination of plants from markets of Dantokpa, Vossa, and Godomey with heavy metals. Senna from Vossa was higher in cadmium and lead levels (Pb: $2.733 \mathrm{mg} / \mathrm{kg} \pm 0.356 \mathrm{mg} / \mathrm{kg} ; \mathrm{Cd}: 0.58 \mathrm{mg} / \mathrm{kg} \pm 0.044 \mathrm{mg} / \mathrm{kg}$ ) compared to the two other places (Pb: $1.825 \mathrm{mg} / \mathrm{kg} \pm 0.133 \mathrm{mg} / \mathrm{kg}, \mathrm{Cd}: 0.062 \mathrm{mg} / \mathrm{kg} \pm 0.015 \mathrm{mg} / \mathrm{kg}$ and $\mathrm{Pb}: 1.902 \mathrm{mg} / \mathrm{kg} \pm 0.265 \mathrm{mg} / \mathrm{kg}, \mathrm{Cd}: 0.328 \mathrm{mg} / \mathrm{kg} \pm 0.024 \mathrm{mg} / \mathrm{kg})$, respectively, for Dantokpa and Godomey. In terms of risk assessment through the consumption of Senna, the values recorded for lead were nine times higher with children and six times higher with adults than the daily permissive intake $(\mathrm{Pb}: 3.376 \times$ $10^{-2} \mathrm{mg} / \mathrm{kg} / \mathrm{day}$ for children and $2.105 \times 10^{-2} \mathrm{mg} / \mathrm{kg} /$ day for adults versus $3.6 \times 10^{-3} \mathrm{mg} / \mathrm{kg} / \mathrm{day}$ for DPI). With respect to cadmium, there was no significant difference between the recorded values and the DPI (Cd: $1 \times 1410^{-3} \mathrm{mg} / \mathrm{kg} / \mathrm{day}$ for children and Cd: $0.71 \times$ $10^{-3} \mathrm{mg} / \mathrm{kg} /$ day for adults versus Cd: $1 \times 10^{-3} \mathrm{mg} / \mathrm{kg} /$ day for adults). This exposure of the population to lead and cadmium through the consumption of antimalarial healing plants could pose public health problems.
\end{abstract}

\section{Introduction}

Air emissions of lead and cadmium are mainly anthropological [1]. Indeed, numerous authors brought to light an increase of 20 factors in connection with human activities during the last two centuries $[2,3]$. And currently the main sources are still fuel combustion in urban zones and the use of fungicides in rural areas $[4,5]$. This study aims at assessing the risks of exposure to lead and cadmium connected to the consumption of Senna rotundifolia Linn. in Cotonou. The plant Senna rotundifolia Linn. was chosen because it is the first plant that is the most frequently bought in markets during the ethnobotanical survey. Benin has been facing enormous problems of environmental pollution connected to 
the production, installations, storage, or treatment process of wastes or pollutants. This situation is amplified by the problems of purification of liquid and solid wastes, draining muds, and household and nonhousehold wastes [6] following the important urban pressure. Certainly, this situation may entail the contamination with pollutants-in this particular case toxic heavy metals of all compartments of the environmentbut the ground is the main target.

Heavy metals spread up in grounds under various forms. Their forms depend on the dynamics of their mineralogical composition, salinity, $\mathrm{pH}$, redox conditions, granulometry of the ground, its moisture content, and the presence of microorganisms [7]. All these factors influence the solubility of metals or their adsorption [8]. Heavy metals are persistent in the ground because they are not degradable by chemical or biological processes [7]. If they are not present in the metallic state, they can settle in clays or in organic matters by ionic connection or form complexes in solution. They can also form inorganic compounds or settle on the surface of particles by adsorption [7]. In this way, they accumulate in the ground where they are drained by run-off water in deeper layers, possibly up to groundwaters [9].

Situated in the interface between water, atmosphere, and vegetables, the ground ensures numerous functions: economic, ecological, and biological [10]. Supporting numerous human activities (industrialization, urbanization, and agriculture), its main role regarding the environment has long been admitted. The ground intervenes as a reactor, a receiver, an accumulator, and a filter of pollutions [11]. However, there was really no serious focus set on the implication of the ground in the cycle of matter and the ground was thought to absorb. On the contrary, toxic heavy metals accumulate in the ground where they may enter the food chain through vegetables [12]. The concentration in toxic heavy metals increase by time [13]. These metals may be released when the environment is altered (acidification of the ground under the influence of changes in temperature, humidity, etc.) and can thus constitute a real time threat. The first victims are the vegetables among which are healing plants.

On the other hand, there is no need to prove the presence of toxic heavy metals in the food intake of Beninese $[14,15]$. Concerning Benin, the first works conducted in the field of toxicology showed that the marine environment is strongly polluted by heavy metals, as well as the water, sediments, and fishing products [16]. Agonkpahoun [17] analyzed the water, the sediments and the fishing products of Lake Nokoue and River Okpara. Studies carried out by Guedenon et al. [18] and Hounkpatin et al. [19], respectively, in Oueme river at Bonou and the lakeside city of Ganvié revealed high levels of heavy metals in continental waters of Benin. Gnandi et al. [20] reported the bioaccumulation of certain trace elements in market-gardened products cultivated on the urban grounds along the highway Lomé-Aného (south Togo).

Toxic heavy metals were found in snails [14], grounds, and vegetables $[15,21]$. The risks of affecting human health were estimated for toxic heavy metals. Indeed, lead and cadmium are poisons for the metabolism.

In fact, absorption of lead depends on the physical and chemical state of the metal and is influenced by age, physiological status, nutritional status, and genetic factors [22]. In the general public, exposure to lead occurs primarily through the oral route, with some contribution from inhalation [23]. Gastrointestinal absorption of lead is affected by physicochemical characteristics of the lead particles and by physiological factors including age, fasting, nutritional calcium and iron statuses, and pregnancy [24]. In adults without occupational exposure and in older children, lead absorbed by the gastrointestinal tract comes mainly from the intake of lead from food, drink, and soil/dust. In adults, approximately $5-15 \%$ of ingested lead is absorbed in the gut whereas in children and infants absorption may be as high as $40 \%$ [25, 26]. Low levels of calcium, iron, copper, zinc, selenium, or phosphate in the diet can increase lead absorption [22, 24, 26].

As for cadmium, absorption following oral exposure is largely dependent on the solubility of its compound but also physiological and nutritional factors may modify the amount absorbed. Absorption from the gastrointestinal tract appears to be a saturable process, as the amount absorbed is decreased at higher doses. Cadmium absorption may be decreased by divalent and trivalent cations $\left(\mathrm{Zn}^{2+}, \mathrm{Mg}^{2+}\right.$, or $\mathrm{Cr}^{3+}$ ) and increased by iron and calcium deficiencies [27]. Cadmium is widely distributed in the body bound mainly to red blood cells or high molecular weight proteins in the plasma. Cadmium is accumulated (50-70\% of body burden) in the kidneys and liver, where it induces the production of metallothionein that binds approximately $80-90 \%$ of cadmium in the body [28]. There is little or no metabolism of cadmium, although it binds to various macromolecules and proteins [27]. Metallothionein is largely involved in the binding of cadmium, which is generally thought to reduce the toxicity of cadmium. In the liver, its production is sufficient to bind all cadmium accumulated. The metallothionein-bound cadmium is released from the liver into the blood where it is cleared by glomerular filtration in the kidney and taken up by the renal tubules, where the metallothionein is cleaved and cadmium is released. As a small fraction of the cadmium is absorbed from the GI tract following ingestion, most of the oral dose is excreted in the faeces.

Lead and cadmium were particularly studied because they are among the most toxic metals for man, particularly causing more or less serious neurological lesions [29].

This study aims at assessing the levels of contamination of antimalarial healing plants with heavy metals in Cotonou on the one hand and on the other hand assessing the exposure risk to lead and cadmium of the population through the consumption of these plants.

\section{Materials and Methods}

2.1. Study Area. Cotonou is the location that served as study area (Figure 1) for our ethnobotanical study. This survey was carried out in 17 markets (the number was required by the protocol of ATRM method) and consisted in threefold purchase of antimalarial medical recipes (markets of Wologuede, Sainte-Rita, Fifadji, Zogbo, Menontin, Kindonou, Godomey, Adjatokpa, Vedoko, Casse-Auto, Vossa, Vodje-Rail, Aidjedo, Saint-Michel, Dantokpa, Gbegamey, and Fidjrosse). 


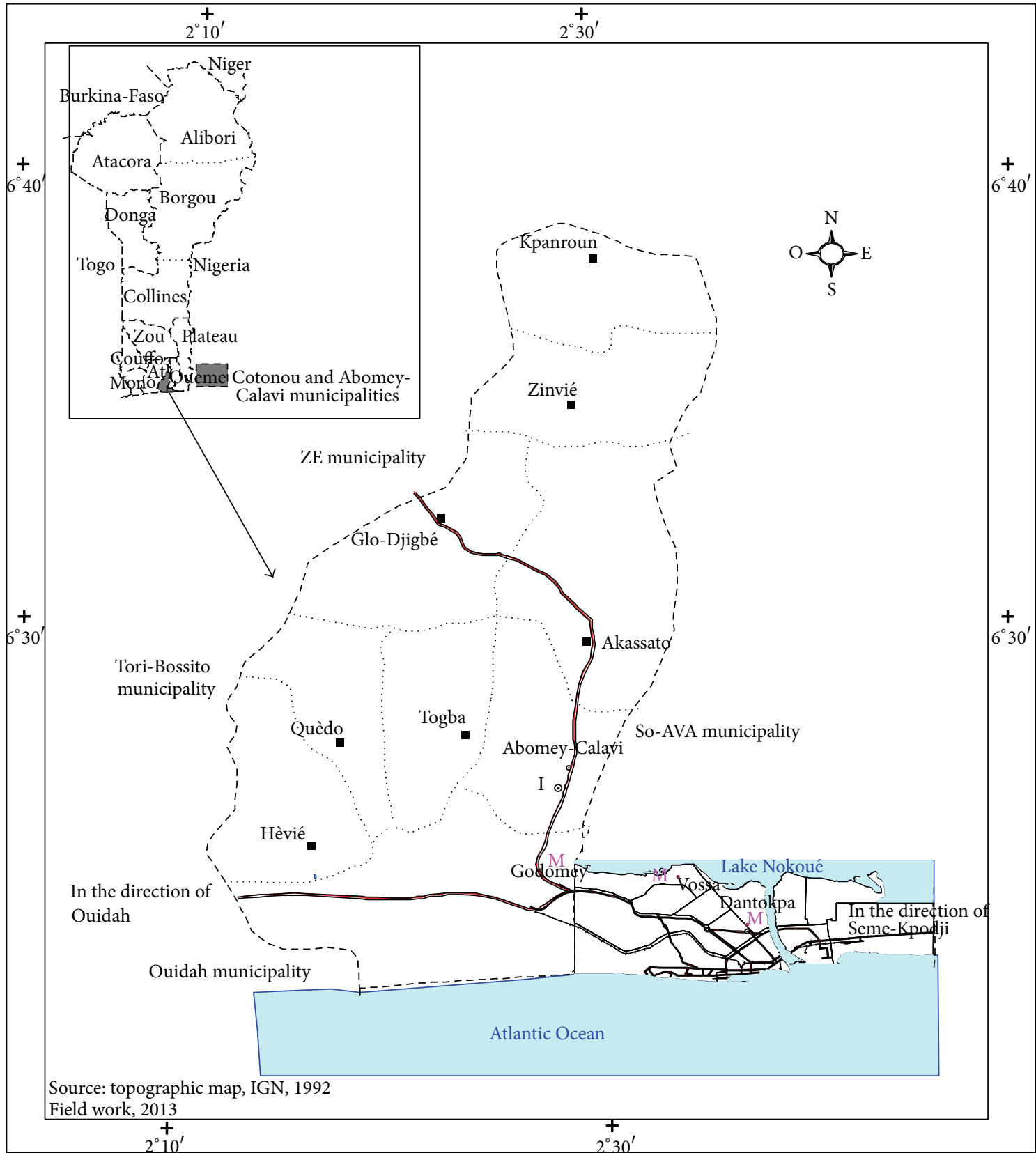

M Study market

- Headquarter of municipality

- Headquarter of road Asphalt road
Border between municipalities

Border between districts

Atlantic Ocean

FIGURE 1: Study area location.

2.2. Sampling and Heavy Metals Analyses of Antimalarial Plants. Senna rotundifolia Linn. was purchased in November 2010 from the three markets that concern this study and was identified by a plant taxonomist. It belongs to the Fabaceae family.

Senna rotundifolia Linn. was analysed for lead and cadmium by atomic absorption spectrophotometer of AAS 110 .
Lead and cadmium were analyzed in the Laboratory of Sciences of Earth, Waters and Environment (LSGWE) of the National Institute of Agriculture Researches in Benin (INRAB) in Republic of Benin by flame atomic absorption spectrophotometer (SAA) 110 following the guidelines of NF reference ISO on 11461995 and NF X 31-147 1996. The plants were mineralized before heavy metals analyses. The data were processed with Excel. 
2.3. Enquiry. A poll was carried out on two hundred children in the range of 10 months- 5 years whose parents were used to purchasing the leaves of Senna rotundifolia for prevention and treatment of malaria.

2.4. Preparation of Decoction. The decoction was done following the guidelines by phytotherapists: $500 \mathrm{~g}$ of fresh leaves of Senna rotundifolia was boiled in $1.5 \mathrm{~L}$ of tap water for twenty minutes.

2.5. Choice of Market for Risk Assessment. Dantokpa market is the biggest market in Cotonou and receives the visit of the highest number of consumers. It even supplies other markets in medicinal plants. That is the reason it was chosen for the risk assessment survey.

2.6. Procedure of Risk Assessment. It is based on the method standardized by Ricoux and Gasztowtt [30].

The approach of risk assessment which is standardized by Ricoux and Gasztowtt [30] is conducted in four stages:

(i) selection of substances and identification of dangers;

(ii) selection of the toxicologic reference values;

(iii) assessment of the exposure by crossing the levels of contamination of plants with $\mathrm{Pb}$ and $\mathrm{Cd}$ and the quantities consumed by a sample of the population. The data on the habits, the quantity, and the frequency of consumption of plants were collected through opinion poll;

(iv) last but not least, the characterization of the risk which represents the synthesis stage of the approach, the presentation, and discussion of the results related to the calculation of the danger quotient (DQ).

\section{Results}

3.1. Toxicological Reference Values. The safety values of daily permissive intake (DPI) by French Agency of Sanitary and Food Safety (AFSSA) [31] for cadmium and lead are, respectively, $1 \times 10^{-3} \mathrm{mg} / \mathrm{kg}$ and $3.6 \times 10^{-3} \mathrm{mg} / \mathrm{kg}$ per body weight (BW). Also, the permissive limits for cadmium and lead by WHO [32] in any food product meant for consumption are, respectively, $0.2 \mathrm{mg} / \mathrm{kg}$ and $0.3 \mathrm{mg} / \mathrm{kg}$ and as healing plants are considered as food, the aforementioned standard was taken into consideration.

3.2. Data Collection of Consumption of Plants. Table 1 summarizes the data collected with regard to levels of consumption of healing plants in the study area.

The results of the survey concerned 200 children from 10 months to 5 years old.

3.3. Dose. From the survey, it came up that $17 \%$ of the children whose ages ranged between 3 and 5 years old received three times the dose of $0.25 \mathrm{~L}$ and that dose is applicable to adults whereas children below three years old received the dose of $0.1 \mathrm{~L}$.
TABLE 1: Results of the survey on the consumption quantity of herb teas.

\begin{tabular}{lccc}
\hline $\begin{array}{l}\text { Consumption } \\
\text { frequency }\end{array}$ & $\begin{array}{c}\text { Quantity } \\
(\mathrm{L})\end{array}$ & $\begin{array}{c}\text { Total volume/day } \\
(\mathrm{L})\end{array}$ & \%Children \\
\hline At least 3 times/day & 0.25 & 0.75 & 17 \\
& 0.10 & 0.30 & 83 \\
\hline
\end{tabular}

The quantities were estimated according to the volumes of herbal teas of Senna rotundifolia L. adopted by parents who give these herbal teas at least once a day to their children.

The minimal mean quantity of herbal teas consumed by a child in a day is the median $M$ :

$$
M=\frac{(0.25 \times 17 \times 3+0.10 \times 83 \times 3)}{100}=0.37 \mathrm{~L} .
$$

3.4. Measurement of Lead and Cadmium in Senna rotundifolia Linn. In the present study, Senna rotundifolia L., which is the most frequently bought species in the biggest market of Cotonou (Dantokpa), was chosen for the risk assessment.

Table 2 presents the results of lead and cadmium concentrations in Senna rotundifolia Linn. in three markets.

For lead, there is no significant difference between mean values with the same letter; however, there is a high significant difference between values with different letters $(P=0.000)$. The same applies to $\mathrm{Cd}$.

Apart from Cd mean value recorded at Dantokpa which showed no difference with safety value, all the mean values are highly above the permissive values by WHO $(P=0.000)$.

Senna rotundifolia $\mathrm{L}$. is contaminated with lead and cadmium and the mean concentrations were, respectively, $1.825 \pm 0.133 \mathrm{ppm}$ and $0.062 \pm 0.015 \mathrm{ppm}$.

3.5. Characterization of the Risk: Calculation of the DED (Daily Exposure Dose). For Senna rotundifolia Linn. contaminated with $\mathrm{Pb}$ and consumed by the children,

$$
\mathrm{DED}_{\mathrm{Pb}}=\frac{\left(\mathrm{Q} \times C_{\mathrm{Pb}}\right)}{\mathrm{BW}},
$$

where $\mathrm{DED}_{\mathrm{Pb}}$ is daily exposure dose for lead, $Q=$ $0.37 \mathrm{~L} /$ day $=0.37 \mathrm{~kg} /$ day (mean quantity of Senna rotundifolia L. consumed by a child), $C_{\mathrm{Pb}}=1.825 \mathrm{mg} / \mathrm{kg}=1825 \mu \mathrm{g} / \mathrm{kg}$ (lead mean concentration in Senna rotundifolia L.), and BW = $20 \mathrm{~kg}$ [31] (body weight of the consumer (child)).

Thus,

$$
\begin{aligned}
\mathrm{DED}_{\mathrm{Pb}} & =\frac{(0.37 \mathrm{Kg} / \text { day } \times 1825 \mu \mathrm{g} / \mathrm{kg})}{20 \mathrm{~kg}} \\
& =3.376 \times 10^{-2} \mathrm{mg} / \mathrm{kg} .
\end{aligned}
$$

For an adult of $65 \mathrm{~kg}$, DED is

$$
\begin{aligned}
\mathrm{DED}_{\mathrm{Pb}} & =\frac{(0.25 \mathrm{~kg} / \text { day } \times 3 \times 1825 \mu \mathrm{g} / \mathrm{kg})}{65 \mathrm{~kg}} \\
& =2.105 \times 10^{-2} \mathrm{mg} / \mathrm{kg} .
\end{aligned}
$$


TABLE 2: Content of lead and cadmium in Senna rotundifolia L. in three markets.

\begin{tabular}{|c|c|c|c|c|c|c|}
\hline \multirow{3}{*}{$\begin{array}{l}\text { (WHO 1998) } \\
\text { Markets }\end{array}$} & \multicolumn{3}{|c|}{ Lead (ppm) } & \multicolumn{3}{|c|}{ Cadmium (ppm) } \\
\hline & & 0.3 & & & 0.2 & \\
\hline & Dantokpa & Godomey & Vossa & Dantokpa & Godomey & Vossa \\
\hline \multirow{5}{*}{ Senna rotundifolia } & 1.711 & 2.302 & 2.833 & 0.055 & 0.345 & 0.589 \\
\hline & 1.823 & 2.033 & 3.199 & 0.079 & 0.359 & 0.581 \\
\hline & 1.677 & 1.644 & 2.226 & 0.078 & 0.298 & 0.592 \\
\hline & 1.986 & 1.763 & 2.6 & 0.051 & 0.315 & 0.639 \\
\hline & 1.928 & 1.768 & 2.807 & 0.047 & 0.323 & 0.514 \\
\hline \multirow{2}{*}{ Mean \pm SD } & $1.825^{\mathrm{a}}$ & $1.902^{\mathrm{a}}$ & $2.733^{\mathrm{b}}$ & $0.062^{\mathrm{a}}$ & $0.328^{\mathrm{b}}$ & $0.583^{c}$ \\
\hline & \pm 0.133 & \pm 0.265 & \pm 0.356 & \pm 0.015 & \pm 0.024 & \pm 0.044 \\
\hline
\end{tabular}

TABLE 3: Daily average intake and daily doses of food exposure to lead and cadmium.

\begin{tabular}{lcc}
\hline DPI and DDE $/$ metals & Lead & Cadmium \\
\hline DPI child 3-5 years & $52 \mu \mathrm{g} /$ day & $7.6 \mu \mathrm{g} /$ day \\
DED per child $(20 \mathrm{~kg})$ & $2.60 \mu \mathrm{g} / \mathrm{kg} /$ day & $0.38 \mu \mathrm{g} / \mathrm{kg} /$ day \\
DED per adult & $0.68 \mu \mathrm{g} / \mathrm{kg} /$ day & $0.16 \mu \mathrm{g} / \mathrm{kg} /$ day \\
\hline
\end{tabular}

For Senna rotundifolia Linn. contaminated by $\mathrm{Cd}$ and consumed by children we have the following.

With the aforementioned formulae

$$
\begin{aligned}
& Q_{\mathrm{Cd}}=0.37 \mathrm{~L} / \text { day }=0.37 \mathrm{~kg} / \text { day } \\
& C_{\mathrm{Cd}}=0.062 \mathrm{mg} / \mathrm{kg}=62 \mu \mathrm{g} / \mathrm{kg} \\
& \mathrm{BW}=20 \mathrm{~kg}[31] .
\end{aligned}
$$

Thus,

$$
\mathrm{DED}_{\mathrm{Cd}}=\frac{(0.37 \mathrm{~kg} / \mathrm{day} \times 62 \mu \mathrm{g} / \mathrm{kg})}{20 \mathrm{~kg}}=1.14 \times 10^{-3} \mathrm{mg} / \mathrm{kg}
$$

For an adult of $65 \mathrm{~kg}$, the DED is

$$
\begin{aligned}
\mathrm{DED}_{\mathrm{Cd}} & =\frac{(0.25 \mathrm{~kg} / \text { day } \times 3 \times 62 \mu \mathrm{g} / \mathrm{kg})}{65 \mathrm{~kg}} \\
& =0.71 \times 10^{-3} \mathrm{mg} / \mathrm{kg} .
\end{aligned}
$$

In addition to $\mathrm{DED}_{\mathrm{Cd}}$ and $\mathrm{DED}_{\mathrm{Pb}}$ through consumption of plant tea, there could be exposure to cadmium and lead through average daily food intake (ADFI). That DED is known as DED of general feeding.

Table 3 shows the amount of lead and cadmium brought in by the average daily food intake of a child (ADFI) and the DED of the general feeding [31].

DED child is daily dose of total exposure for a toxicant expressed. $\mathrm{DED}_{\mathrm{PT}}$ is daily dose of exposure through the consumption of Senna rotundifolia $\mathrm{L}$. contaminated with a toxicant. $\mathrm{DED}_{\mathrm{FI}}$ is daily dose of exposure to a toxicant through general feeding.
Thus,

$$
\begin{aligned}
\text { for } \mathrm{Pb}, \text { DED child } & =33.76 \mu \mathrm{g} / \mathrm{kg} / \text { day }+2.60 \mu \mathrm{g} / \mathrm{kg} / \text { day } \\
& =3.636 \times 10^{-2} \mathrm{mg} / \mathrm{kg} / \text { day; } \\
\text { for Cd, DED child } & =1.14 \mu \mathrm{g} / \mathrm{kg} / \text { day }+0.38 \mu \mathrm{g} / \mathrm{kg} / \text { day } \\
& =1.52 \times 10^{-3} \mathrm{mg} / \mathrm{kg} / \text { day }
\end{aligned}
$$

In theory, considering the fact that for an adult the meals are often the same within households, the DED for an adult is

$$
\text { DDE per adult }=(\text { DED child } \times \text { AW child }) \text { AW of adult, }
$$

where DED child is daily dose of exposure for child, DED adult is daily dose of exposure for adult, and AW is average weight of an adult $=65 \mathrm{~kg}$.

Thus,

$$
\begin{aligned}
\text { for } \mathrm{Pb} \text {, adult } \mathrm{DED} & =\frac{(36.36 \mu \mathrm{g} / \mathrm{kg} / \text { day } \times 20)}{65} \\
& =1.118 \times 10^{-2} \mathrm{mg} / \mathrm{kg} / \text { day; } \\
\text { for } \mathrm{Cd} \text {, adult } \mathrm{DDE} & =\frac{(1.52 \mu \mathrm{g} / \mathrm{kg} / \text { day } \times 20)}{65} \\
& =0.46 \times 10^{-3} \mathrm{mg} / \mathrm{kg} / \text { day }
\end{aligned}
$$

3.6. Calculation of Danger Quotients. The danger quotient is defined by the relationship between the DDE observed on average and the corresponding $\mathrm{BDD}$ according to the formula

$$
\mathrm{DQ}=\frac{\text { total } \mathrm{DED}}{\mathrm{BDD}}
$$

with

$\mathrm{DQ}=$ danger quotient,

total DED = daily dose of total exposure,

$\mathrm{BDD}=$ bearable daily; for lead $=3.6 \mu \mathrm{g} / \mathrm{kg} /$ day . 
TABLE 4: Summary of results for assessment of exposure to $\mathrm{Pb}$ and $\mathrm{Cd}$.

\begin{tabular}{|c|c|c|c|c|c|c|c|c|c|c|}
\hline & \multirow{2}{*}{ Q (kg/day) } & \multirow{2}{*}{$\mathrm{Ce}(\mathrm{mg} / \mathrm{kg})$} & \multicolumn{2}{|c|}{ BW (kg) } & \multicolumn{2}{|c|}{ DED (mg/kg/day) } & \multicolumn{2}{|c|}{ DED total $(\mathrm{mg} / \mathrm{kg} /$ day $)$} & \multicolumn{2}{|c|}{ DQ } \\
\hline & & & Child & Adult & Child & Adult & Child & adult & Child & Adult \\
\hline Lead & 0.37 & 1.825 & 20 & 65 & $\begin{array}{c}3.376 \\
10^{-2}\end{array}$ & $\begin{array}{l}2.105 \\
10^{-2}\end{array}$ & $\begin{array}{c}3.6 \\
10^{-2}\end{array}$ & $\begin{array}{l}1.118 \\
10^{-2}\end{array}$ & 10.10 & 3.10 \\
\hline Cadmium & & 0.062 & & & $\begin{array}{c}1.14 \\
10^{-3} \\
\end{array}$ & $\begin{array}{l}0.71 \\
10^{-3} \\
\end{array}$ & $\begin{array}{l}1.52 \\
10^{-3} \\
\end{array}$ & $\begin{array}{l}0.46 \\
10^{-3} \\
\end{array}$ & 1.52 & 0.46 \\
\hline
\end{tabular}

DED: daily dose of exposure; Total DED: daily dose of total exposure; Q: mean quantity of herbal tea consumed by a child; Ce: average concentration of lead or cadmium measured in Senna rotundifolia L.; BW: body weight of the consumer; DQ: danger quotient.

For children,

$$
\begin{aligned}
& \text { DQ of lead }=36.36 \mu \mathrm{g} / \mathrm{kg} / \mathrm{day} /(3.6 \mu \mathrm{g} / \mathrm{kg} / \text { day })=10.10, \\
& \text { DQ of cadmium }=1.52 \mu \mathrm{g} / \mathrm{kg} / \text { day } /(1 \mu \mathrm{g} / \mathrm{kg} / \text { day })=1.52
\end{aligned}
$$

For adults,

DQ of lead $=11.18 \mu \mathrm{g} / \mathrm{kg} / \mathrm{day} /(3.6 \mu \mathrm{g} / \mathrm{kg} /$ day $)=3.10$, DQ of cadmium $=0.46 \mu \mathrm{g} / \mathrm{kg} / \mathrm{day} /(1 \mu \mathrm{g} / \mathrm{kg} /$ day $)=$ 0.46 .

Table 4 presents the main results of exposure assessment to $\mathrm{Pb}$ and $\mathrm{Cd}$ through the consumption of contaminated plants.

\section{Discussion}

The assessment of the exposure of the target population to lead and cadmium through the consumption of herbal teas made of Senna rotundifolia Linn. required the analysis of two sources of data in accordance with Ricoux and Gasztowtt [30] guidelines: information about the frequency of consumption of herbal tea through poll opinion (Table 1) and the results of lead and cadmium analyses in Senna rotundifolia with atomic absorption spectrophotometer (Table 2). The mean concentrations for lead and cadmium were, respectively, $1.825 \mathrm{ppm}$ \pm 0.133 and $0.062 \mathrm{ppm} \pm 0.015$. These mean concentrations in the herbal tea were above WHO [32] standards which are, respectively, $0.3 \mathrm{ppm}$ and $0.2 \mathrm{ppm}$. It was also noticed that Senna rotundifolia Linn. from Vossa was higher in cadmium and lead levels ( $\mathrm{Pb}: 2.733 \mathrm{mg} / \mathrm{kg} \pm 0.356 \mathrm{mg} / \mathrm{kg}$; Cd: $0.58 \mathrm{mg} / \mathrm{kg} \pm 0.044 \mathrm{mg} / \mathrm{kg}$ ) compared to the two other places (Pb: $1.825 \mathrm{mg} / \mathrm{kg} \pm 0.133 \mathrm{mg} / \mathrm{kg} ; \mathrm{Cd}: 0.062 \mathrm{mg} / \mathrm{kg}$ $\pm 0.015 \mathrm{mg} / \mathrm{kg}$ and $\mathrm{Pb}: 1.902 \mathrm{mg} / \mathrm{kg} \pm 0.265 \mathrm{mg} / \mathrm{kg}$; Cd: $0.328 \mathrm{mg} / \mathrm{kg} \pm 0.024 \mathrm{mg} / \mathrm{kg}$ ), respectively, for Dantokpa and Godomey. In fact, Vossa is notoriously well-known as the most unsafe place of Cotonou. It is a swampy area where pigs are errand. So inadequate freser vation of the plants could explain the highest levels of heavy metals in that place of our study area. Besides, the DED for a $20 \mathrm{~kg}$ child was 3.376 $\times 10^{-2} \mathrm{mg} / \mathrm{kg}$ for $\mathrm{Pb}$ and $1.14 \times 10^{-3} \mathrm{mg} / \mathrm{kg}$ for $\mathrm{Cd}$. These values of DED (especially for lead) were highly above the permissive values by WHO [32] which are, respectively, $3.6 \times$ $10^{-3} \mathrm{mg} / \mathrm{kg}$ and $1 \times 10^{-3} \mathrm{mg} / \mathrm{kg}$. Also the DED obtained for a child were much higher than those with adults of $65 \mathrm{~kg}$ which were, respectively, $2.105 \times 10^{-2} \mathrm{mg} / \mathrm{kg}$ and $0.71 \times 10^{-3} \mathrm{mg} / \mathrm{kg}$ for lead and cadmium. However, the daily exposure dose recorded through the general food intake $\left(\mathrm{DED}_{\mathrm{FI}}\right)$ must be added to that DED recorded for children through plants infusion considering the fact that children are exposed to the same metal via other foods in the same way as the general population [24]. The average daily food intake (ADFI) and the daily doses of exposure $\left(\mathrm{DED}_{\mathrm{FI}}\right)$ registered through the general feeding just for lead presented in Table 3 imply that other food items are contaminated in the same way as plants. The results revealed that the daily doses of total exposure for lead and cadmium were, respectively, lower in adults $(1.118 \times$ $10^{-3} \mathrm{mg} / \mathrm{kg} /$ day and $0.46 \times 10^{-3} \mathrm{mg} / \mathrm{kg} /$ day) than in children $\left(3.636 \times 10^{-2} \mathrm{mg} / \mathrm{kg} /\right.$ day and $1.52 \times 10^{-3} \mathrm{mg} / \mathrm{kg} /$ day $)$. In every case the danger quotient is alarmingly higher in children (10.10 and 1.52) than in adults (3.10 and 0.46). So children pay a double levy to this pollution because not only are they more exposed but also their bodies are more fragile. Indeed, children are more exposed to heavy metals than adults when considering their age, weight, and their food requirement and therefore their food intake is twice higher than that of adults and by taking in food, they are taking in lead and cadmium as well [33]. Children potentially absorb more contaminants because they spend more time outside to play and are more exposed to airborne contaminants [33]. In contrast, the clearance of heavy metals from younger individuals is slower compared to adults due to their excretion system which is not so well developed [33]. As a result, the absorbed toxicants can be more harmful to children.

Moreover, there is an excess of risk for an average consumption of $0.37 \mathrm{~L} /$ day of contaminated herb teas from Dantokpa market. This is not the case in adults where the risk usually proves to be lower. Of course, adults are victims of contamination or poisoning with lead and cadmium but when young children are affected, their health is particularly in danger. Very small quantities of metals can impair their cognitive development and cause attention problems. In fact, when an important proportion of pollutants and particularly lead is introduced into the body, approximately 25\% remain in children's bloodstream and exert their neurotoxic damage. But in comparison to adults, only $5 \%$ to $10 \%$ of the absorbed lead remains in bloodstream. The rest settles in bones and teeth [34]. The daily doses of exposure to lead via the consumption of herb teas with Senna rotundifolia $\mathrm{L}$. that were $3.636 \times 10^{-2} \mathrm{mg} / \mathrm{kg} /$ day for lead and $1.52 \times 10^{-3} \mathrm{mg} / \mathrm{kg} /$ day for cadmium were higher than those via food intake which are $2.60 \times 10^{-3} \mathrm{mg} / \mathrm{kg} /$ day for $\mathrm{Pb}$ and $0.68 \times 10^{-3} \mathrm{mg} / \mathrm{kg} /$ day for $\mathrm{Cd}$. It could be inferred from the comparison that the 
exposure to lead is more important via the consumption of the plants than the other sources of food (Table 4). Besides, the data recorded with the population of the study area can be extrapolated to all the children in the region because of the relative homogeneity of the averages of lead and cadmium contents recorded in plants [30].

The results of the actual risk assessment accord with those of Kim et al. [35] which observed that oriental herbs in Korea contained pollutants and heavy metals. This study was the first one to estimate the exposure and risk of poisoning with heavy metals according to the standard method of Ricoux and Gasztowtt [30].

\section{Conclusion}

The objective of this work was to assess the risks of exposure to lead and cadmium in connection to the consumption of Senna rotundifolia Linn. infusion in Cotonou. Indeed the chemical characterization of this species showed that it is contaminated with lead and cadmium in the markets with contents which exceeded the accepted standards. The risk assessment of exposure connected to the consumption of this herb tea following the standardized approach showed that there is risk of accumulation of lead and cadmium in the body with regard to the DED and DQ calculated. Considering these results and knowing as well the fatal effects of lead and cadmium on health, it is important to raise the population's awareness of the sources of potential contamination of the plant with these metals which are essentially agriculture, industry, and the mismanagement of household wastes. The possible accumulation of lead and cadmium in the blood could be a source of pathologies known as autism and cardiorespiratory depression. But to verify this hypothesis in later studies, sampling of blood from exposed population will turn out to be necessary for the revealing of toxicity biomarkers of these metals.

\section{Conflict of Interests}

The authors declare that there is no conflict of interests regarding the publication of this paper.

\section{References}

[1] S. Casas, Modélisation de la bioaccumulation de métaux traces ( $\mathrm{Hg}, \mathrm{Cd}, \mathrm{Pb}, \mathrm{Cu}$ et $\mathrm{Zn}$ ) chez la moule, mytilus Galloprovincialis, en milieu méditerranéen [thèse de doctorat en biochimie et ecotoxicologie], Université du Sud Toulon-Var, 2005.

[2] M. Murozumi, T. J. Chow, and C. Patterson, "Chemical concentrations of pollutant lead aerosols, terrestrial dusts and sea salts in Greenland and Antarctic snow strata," Geochimica et Cosmochimica Acta, vol. 33, no. 10, pp. 1247-1294, 1969.

[3] C. F. Boutron and C. C. Patterson, "The occurrence of lead in Antarctic recent snow, firn deposited over the last two centuries and prehistoric ice," Geochimica et Cosmochimica Acta, vol. 47, no. 8, pp. 1355-1368, 1983.

[4] A. Deluisa, P. Giandon, M. Aichner et al., "Copper pollution in italian vineyard soils," Communications in Soil Science and Plant Analysis, vol. 27, no. 5-8, pp. 1537-1548, 1996.
[5] P. H. Bourrelier and J. Berthelin, Contamination des sols par les éléments en traces: les risques et leur gestion, Académie des Sciences, Techniques et Documentation, Paris, France, 1998.

[6] F. E. Dovonou, Pollution des plans d'eau du Sud-Bénin et risques écotoxicologiques: cas du lac Nokoué. Mémoire de DEA en Environnement, Santé et Développement, CIFRED, UAC, 2009.

[7] G. Chidikofan, Contribution à l'amélioration de la qualité des cultures maraîchères du site de Houéyiho à Cotonou au BENIN: cas de la laitue (Lactuca sativa L.) [mémoire de master], 2IE, Ouagadougou, Burkina Faso, 2010.

[8] A. Bogaerts, Z. Chen, R. Gijbels, and A. Vertes, "Laser ablation for analytical sampling: What can we learn from modeling?" Spectrochimica Acta B, vol. 58, no. 11, pp. 1867-1893, 2003.

[9] D. Baize, Petit lexique de pédologie, INRA, Paris, France, 2004.

[10] Rôle des activités lombriciennes sur la redistribution des éléments traces métalliques issus de boue de station d'épuration dans un sol agricole [thèse de doctorat], UMR ECOBIO, Université de Rennes 1, Paris, France, 2002.

[11] M. Robert and C. Juste, "Enjeux environnementaux et industriels. Dynamique des éléments traces dans l'écosystème sol," in Spéciation des métaux dans le sol, pp. 15-37, Les Cahiers des Clubs CRIN, Paris, France, 1999.

[12] G. Miquel, Les effets des métaux lourds sur l'environnement et la santé. Rapport d'information no. 261 fait au nom de l'Office parlementaire d'évaluation des choix scientifiques et technologiques Sénat, Assemblée Nationale, Paris, France, 2001.

[13] S. A. M. Dossier, Méthodes spectrométriques d'analyse et de caractérisation, Génie des Procédés, Centre SPIN, Ecole des Mines de Saint-Etienne, 1997.

[14] A. P. Edorh, E. Agonkpahoun, K. Gnandi et al., "An assessment of the contamination of Achatina achatina by toxic metals in Okpara village," International Journal of Biological and Chemical Sciences, vol. 3, no. 6, pp. 1428-1436, 2009.

[15] L. Koumolou, A. P. Edorh, L. Agbandji, S. A. Hounkpatin, and B. Elegbede, "Threat of the health quality of garden produces linked to pollution by toxic metals on some gardening sites of Benin," American Journal of Environmental Sciences, vol. 8, no. 3, pp. 248-252, 2012.

[16] E. Montcho, Métaux toxiques dans l'environnement marin au Bénin: evaluation préliminaire de la pollution [Thèse de diplôme d'Etat de docteur en Pharmacie], FSS/UAC, 2005.

[17] E. D. Agonkpahoun, Evaluation de la pollution des eaux continentales par les métaux toxiques: cas de la riviere Okpara et du lac Nokoue au Bénin, 2007.

[18] P. Guedenon, A. P. Edorh, C. Kaki et al., "Arsenic, cadmium, copper and lead accumulation in water, sediments and fish species of Oueme River in Bonou," British Journal of Pharmacology and Toxicology, vol. 3, no. 1, pp. 13-20, 2012.

[19] A. S. Y. Hounkpatin, A. P. Edorh, S. Salifou et al., "Assessment of exposure risk to lead and cadmium via fish consumption in the lacusrian village of Ganvié in Benin republic," Journal of Environmental Chemistry and Ecotoxicology, vol. 4, no. 1, pp. 110, 2012.

[20] K. Gnandi, K. Tozo, P. Edorh et al., "Bioaccumulation de certains éléments métalliques dans les produits maraîchers cultivés sur les sols urbains le long de l'utoroute Lomé- Aného, Sud Togo," Acta Botanica Gallica, vol. 155, no. 3, pp. 415-426, 2008.

[21] T. V. Dougnon, P. A. Edorh, H. S. Bankolé et al., "Evaluation of the toxicological quality of the leaves of Solanum macrocarpum L. cultivated with the chicken's droppings and water of marsh at 
Cotonou (Benin)," Journal of Research in Environmental Science and Toxicology, vol. 1, pp. 1-6, 2012.

[22] International Programme on Chemical Safety (IPCS), "Inorganic lead," Environmental Health Criteria 165, World Health Organisation, Geneva, Switzerland, 1995.

[23] Agency for Toxic Substances and Disease Registry (ATSDR), Toxicological Profile for Lead, US Department of Health and Human Services, Atlanta, Ga, USA, 2007.

[24] EFSA (European Food Safety Authority), "Panel on contaminants in the food chain (CONTAM), scientific opinion on lead in food," EFSA Journal, vol. 8, no. 4, p. 1570, 2010.

[25] International Programme on Chemical Safety (IPCS), "Lead, inorganic," Poisons Information Monograph PIM 301.

[26] International Programme on Chemical Safety, Lead, Monograph for UKPID, IPCS, London, UK.

[27] Risk Assessment Information System (RAIS), Toxicity Summary for Cadmium, Chemical Hazard Evaluation and Communication Group, Biomedical and Environmental Information Analysis Section, Health and Safety Research Division, 1991.

[28] International Programme on Chemical Safety (IPCS), "Cadmium," Environmental Health Criteria 134, World Health Organisation, Geneva, Switzerland, 1992.

[29] F. Testud, Pathologie toxique professionnelle et environnementale, Eska, Paris, France, 3rd edition, 2005.

[30] C. Ricoux and B. Gasztowtt, "Evaluation des risques sanitaires liés à l'exposition de forts consommateurs de produits de la pêche de rivière contaminés par des toxiques de l'environnement," 2005.

[31] Agence Française de Sécurité Sanitaire des Aliments, Institut de veille sanitaire (AFSSA), "Le méthylmercure. Programme "mortalité et morbidité des maladies d’origine alimentaire"Volet toxicologique-Contaminants chimiques et risque alimentaire en France," Document de Travail, 2003.

[32] OMS-IPCS, "World Health Organisation, International Programme on Chemical Safety," Environmental Health Criteria 200, Cooper, 1998.

[33] Royal Commission on Aboriginal Peoples (RCAP), Gathering Strength, vol. 3, Communications Group, Ottawa, Canada, 1996.

[34] M. D. Sanborn, A. Abelsohn, M. Campbell, and E. Weir, "Identifying and managing adverse environmental health effects. 3: lead exposure," Canadian Medical Association Journal, vol. 166, no. 10, pp. 1287-1292, 2002.

[35] H.-K. Kim, E. K. Yoon, J. Jang et al., "Assessment of heavy metal exposure via the intake of oriental medicines in Korea," Journal of Toxicology and Environmental Health A, vol. 72, no. 21-22, pp. 1336-1342, 2009. 

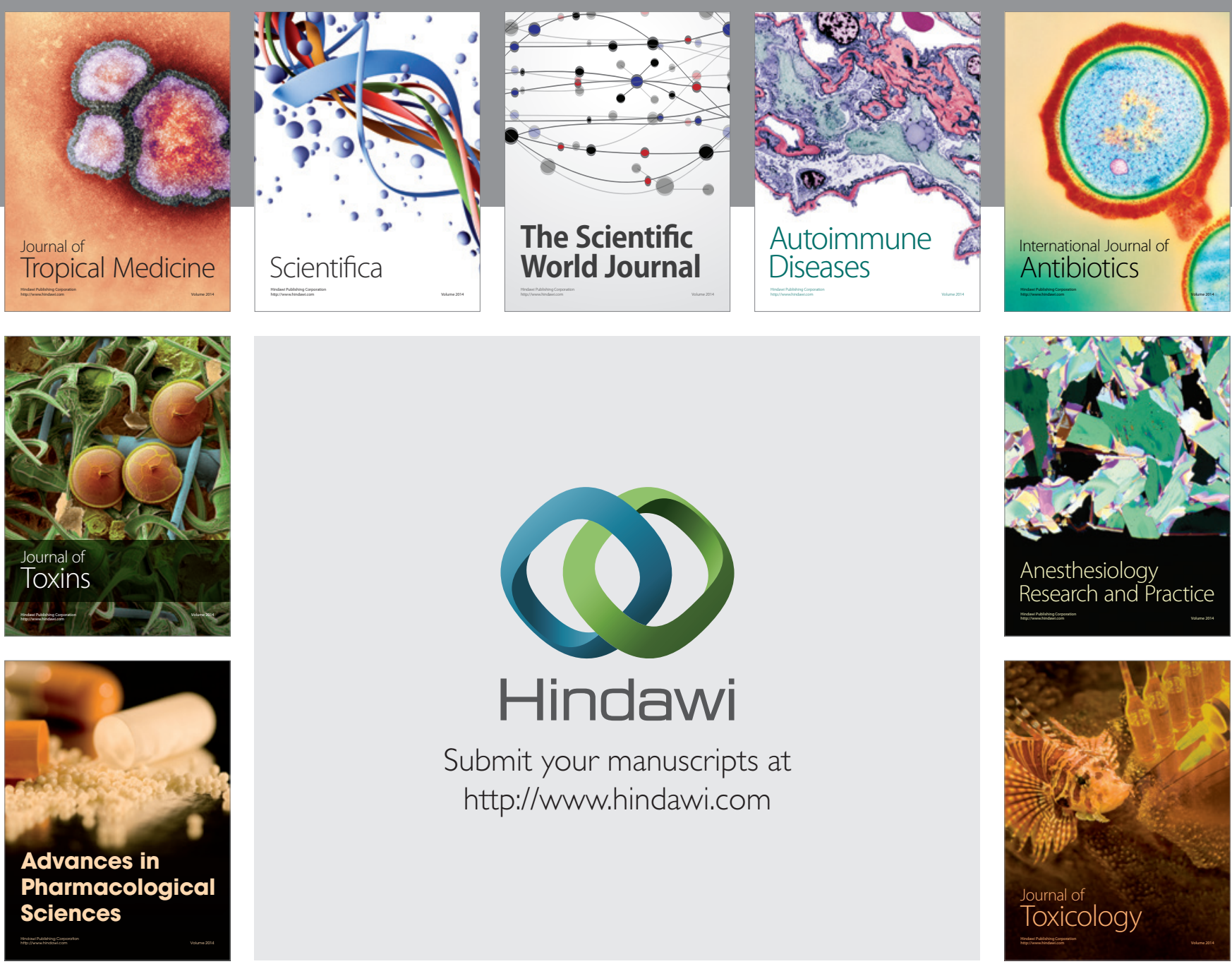

\section{Hindawi}

Submit your manuscripts at

http://www.hindawi.com
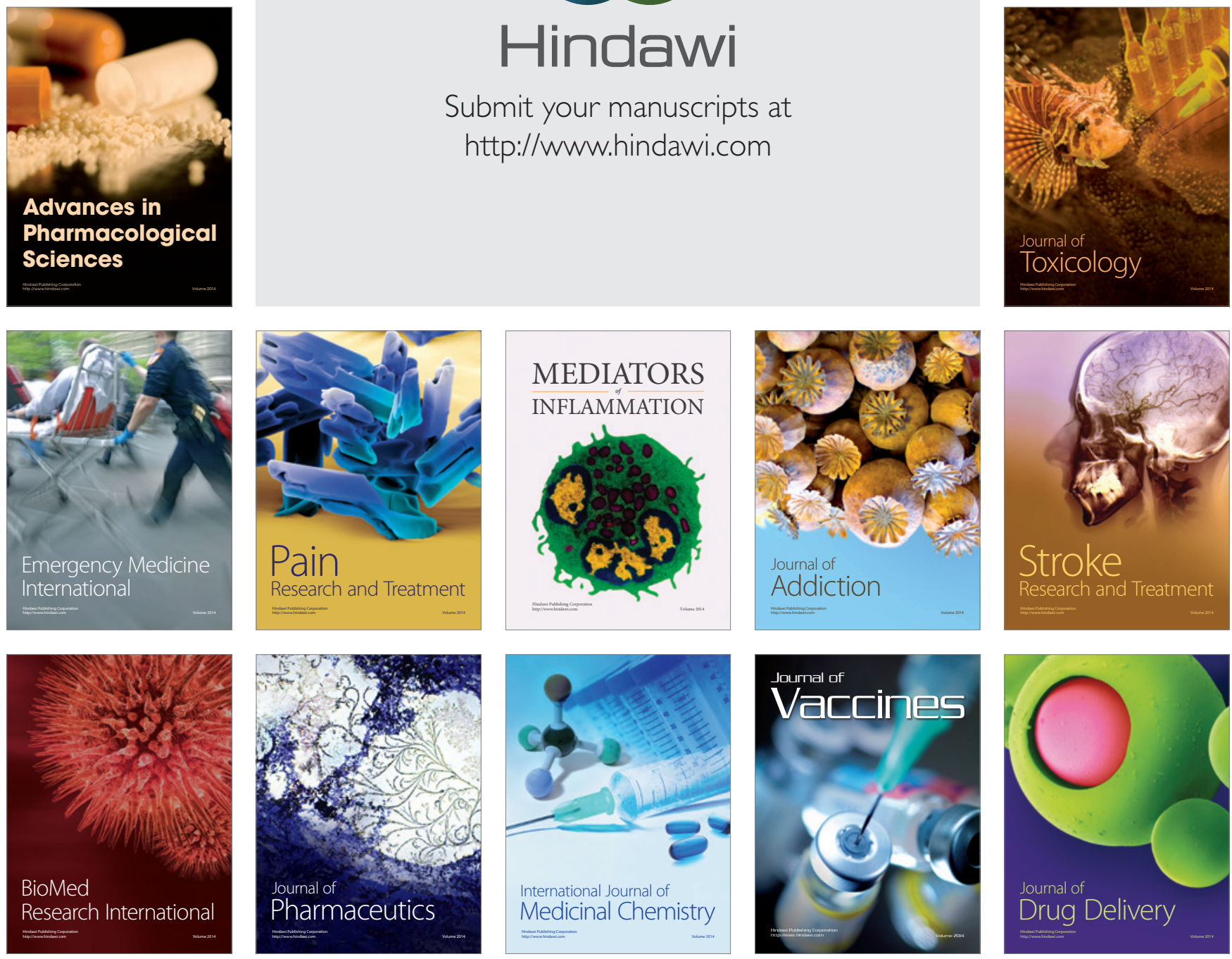